\title{
REPRODUCTIVE PERFORMANCE OF EGYPTIAN BUFFALO HEIFERS FED DIETS SUPPLEMENTED WITH YEAST CULTURE (GASTUR NATURE): 3- OVARIAN ACTIVITY AND PROGESTERONE PROFILE. Abdel-Khalek, E.A.*; H.B. Aboul-Ela ${ }^{\star \star}$ and M.A. Abdel-Latif ${ }^{\star *}$ \\ * Anim. Prod. Dept., Fac. Agric., Mansoura University. \\ ${ }^{\star \star}$ Anim. Prod. Res. Inst., Agric. Res. Center.
}

\begin{abstract}
Eighteen Egyptian buffalo heifers aging 7-11 months and weighing 197 \pm 12.09 $\mathrm{kg}$ LBW were used in this study. The experimental animals were divided into three similar groups according to LBW and age. All animals were fed concentrate feed mixture (CFM), berseem hay $(\mathrm{BH})$ and rice straw (RS). The $1^{\text {st }}$ group was fed CFM, $\mathrm{BH}$ and $\mathrm{RS}$ (control ration $\mathrm{G} 1$ ), and the $2^{\text {nd }}(\mathrm{G} 2)$ and $3^{\text {rd }}(\mathrm{G} 3)$ groups were fed the control diet supplemented with 20 and $30 \mathrm{~g} \mathrm{YC} \mathrm{(Gustor} \mathrm{nature)/h/d,} \mathrm{respectively.}$ Buffalo heifers in all groups were fed the experimental diet up to conception. Ovarian activity was studied and blood was collected for progesterone assay. Results revealed that just prior to puberty, no ovulations occurred in G1 while two silent ovulations occurred in two animals of G2 and 5 silent ovulations in 5 animals of G3. Average $\mathrm{Pg}$ concentration was insignificantly the highest in $\mathrm{G} 3(1.971 \mathrm{ng} / \mathrm{ml})$, followed by $\mathrm{G} 1$ $(1.403 \mathrm{ng} / \mathrm{ml})$ and the lowest in $\mathrm{G} 2(0.957 \mathrm{ng} / \mathrm{ml})$. Age of heifers at $\mathrm{Pg}$ peak was insignificantly lower in G3 (472.1 days) and G2 (491.5 days) than in G1 (519.6 days). From puberty to $1^{\text {st }}$ service, average number of ovarian cycles/animal was $1.0,0.83$ and 0.67 in G1, G2 and G3, respectively. Average and peak of Pg concentration, and interval to $\mathrm{Pg}$ peak showed insignificantly the highest values in $\mathrm{G} 3$, moderate in $\mathrm{G} 1$ and the lowest in G2. From the $1^{\text {st }}$ service to conception, number of ovarian cycles/animal averaged $0.50,0.17$ and 0.50 in G1, G2 and G3, respectively. Number of services per conception and service period were lower in G2 (1.17 and 3.8 days) and higher in G3 (1.5 and 14.7 days) than in $\mathrm{G} 1$ (1.33 and 10.8 days). From prepuberty up to conception, overall length of the oestrous cycles was 20.3, 17.3 and 26.1; overall number of ovulations/animal was $2.5,2.33$ and 3.0 and number of silent ovulations/animal was 0.83 in G3, 0.50 in G2 and 0.33 in G1, respectively. Conception rat was $66.7,83.3$ and $50 \%$ in G1, G2 and G3 after the $1^{\text {st }}$ service, respectively. All heifers were conceived after the $2^{\text {nd }}$ service. Maximum $\mathrm{Pg}$ concentration during the first two weeks of pregnancy was the highest in G3, moderate in G1 and the lowest in G2. This may indicate the beneficial effects of feeding buffalo heifers on diets supplemented with $20 \mathrm{~g} \mathrm{YC/h/day} \mathrm{prior} \mathrm{to} \mathrm{puberty} \mathrm{(5} \mathrm{months)} \mathrm{up} \mathrm{to} \mathrm{conception.}$

Keywords: buffalo heifers, puberty, service, conception, progesterone.
\end{abstract}

\section{INTRODUCTION}

Inadequate nutrition adversely affected the pituitary function through the pattern of releasing and/or producing the pituitary gonadotrphins (Lamminy, 1969). In pre-pubertal heifers, pituitary response to $\mathrm{GnRH}$ differs in terms of LH and FSH release (McLeod et al., 1985) and specific factors such as inhibin differentially regulate $\mathrm{LH}$ and FSH secretion (Ireland et al., 1983). It has been suggested that gonadotropins concentrations are transiently increased prior to puberty age in heifers (Schams et al. 1981 and Evans et al. 1992), but not all investigators have seen this early rise (Dodson et al., 1988). 
Hall et al. (1994) found marked effect of dietary energy on pattern of LH release, follicular development, and onset of puberty in Angus heifers.

Detailed understanding of the endogenous hormonal control of the oestrous cycle is very important for recent application of biotechnology in animal reproduction. The concurrent changes in plasma levels of oestrogen and progesterone $(\mathrm{Pg})$ are most likely to be responsible for the manifestation of oestrous behaviour and subsequent ovulation (Aboul-Ela, 1980; Arora and Pandey, 1982; Hafez, 1987 and Beg and Totey, 1999).

Concentration of $\mathrm{Pg}$ in blood reflects the function of $\mathrm{CL}$. Monitoring $\mathrm{Pg}$ level during the postpartum period is a good indicator for changes in ovarian activity (Perera, 1981; Kamonpatana et al., 1981; Aboul-Ela et al., 1985 and 1987; Barkawi et al., 1986; Barkawi 1993 and El-Wardani et al., 1998).

The current study aimed at evaluating the effects of dietary supplementation of yeast culture (Gustor nature) throughout pre-pubertal ages on, ovarian activity and $\mathrm{Pg}$ concentration of buffalo heifers at prepubertal ages, puberty, $1^{\text {st }}$ service and conception.

\section{MATERIALS AND METHODS}

The present study was carried out at El-Gemmizah Research Station, Gharbia Governorate, belonging to Animal Production Research Institute, Agricultural Research Center, Ministry of Agriculture, in cooperation with Department of Animal Production, Faculty of Agriculture, Mansoura University, during the period from July 2003 to October 2004.

Experimental animals:

Eighteen Egyptian female buffalo heifers aging 7-11 months and having $197 \pm 12.0 \mathrm{~kg}$ LBW were divided randomly into three similar groups balanced for LBW and age ( 6 animals in each). All experimental heifers were housed individually under semi-open shed, partially roofed with asbestos.

\section{Feeding system and experimental groups:}

The main experimental basal diet was formulated from concentrate feed mixture (CFM), berseem hay (BH) and rice straw (RS). Amounts of feedstuffs required for feeding heifers at different LBW classes were the same for all experimental groups. Dry matter content (\%) and calculated chemical composition of experimental diets (on DM basis) are presented in table (1).

Heifers in the control group (G1) were fed CFM, BH and RS (control diet), while those in the $1^{\text {st }}$ and $2^{\text {nd }}$ treated groups (G2 and G3) were fed the control diet supplemented with 20 and $30 \mathrm{~g}$ yeast culture (YC) per head/day, respectively.

The yeast culture was added and mixed with CFM of the diet, immediately before feeding. Heifers in all groups were fed the experimental diets at the beginning of the experiment up to conception. Diets were fed to all groups twice a day at 8 a.m. and 2 p.m. 
Table (1): Dry matter content (\%) and calculated chemical composition of experimental diets (on DM basis).

\begin{tabular}{|c|c|c|c|c|c|c|c|c|c|}
\hline \multirow{2}{*}{ Diet } & \multirow{2}{*}{ DM\% } & \multicolumn{6}{|c|}{ Chemical composition on DM basis (\%) } & \multicolumn{2}{c|}{ eeding values } \\
\cline { 3 - 9 } & & OM & CP & CF & EE & NFE & Ash & TDN\% & DCP\% \\
\hline $\mathrm{D}_{1}$ & 80.29 & 88.58 & 14.00 & 21.43 & 2.70 & 50.45 & 11.42 & 61.21 & 7.90 \\
$\mathrm{D}_{2}$ & 78.72 & 89.73 & 14.62 & 21.41 & 2.85 & 50.85 & 10.27 & 66.50 & 10.35 \\
$\mathrm{D}_{3}$ & 84.56 & 89.96 & 15.00 & 23.00 & 2.25 & 49.71 & 10.04 & 65.36 & 10.97 \\
\hline
\end{tabular}

$\mathrm{D}_{1}$ : Control diet (Unsupplemented for G1). $\mathrm{D}_{2}$ : Diet supplemented with $20 \mathrm{~g}$ YC for G2.

$D_{3}$ : Diet supplemented with $30 \mathrm{~g}$ YC.

Fresh water was available all daytime. Mineral blocks were freely available throughout the experimental period.

Yeast culture (Gustor nature) used in this study was imported from Barcelona, Spain allotted by Egyptic Company. It was contained malic acid salts, Saccharomyces cerevisiae, mould inhibitors, antisalmonella, antioxidants flavors and sweeteners.

\section{Experimental procedures:}

Blood samples were collected from the jugular vein before morning feeding into heparinized test tubes. Within an hour after collection, samples were centrifuged for 15 minutes at $3000 \mathrm{rpm}$, then plasma was separated and stored at $-20^{\circ} \mathrm{C}$ until $\mathrm{Pg}$ assay. Blood samples were collected from all heifers in each group regularly at 3-4 day-interval prior to puberty up to conception. Only plasma samples of approximately one month post the $1^{\text {st }}$ oestrous activity (puberty) were taken from for each animal for progesterone assay.

\section{Reproductive performance:}

\section{Detection of puberty:}

When heifers reached 15 months of age, a teaser bull was introduced to each group for 20 minutes three times daily at 7 a.m , 12 a.m. and 2 p.m. to detect the onset of the $1^{\text {st }}$ oesturs. Heifers being in oestrus were receptive for teaser and stood for mounting by the teaser. The onset of first oestrous was used as an indicator for the onset of puberty.

Puberty was defined as the $1^{\text {st }}$ day that plasma progesterone (determined in blood samples collected at weekly intervals) exceeded $1 \mathrm{ng} / \mathrm{ml}$ and was indicated with heifers exhibiting the first oestrous activity.

\section{Puberty, oestrous activity and service:}

Date of onset of the first oestrous behaviour was recorded and it was considered as an indicator for achieving puberty if concentration of progesterone $(\mathrm{Pg})$ was $\geq 1 \mathrm{ng} / \mathrm{ml}$ in blood plasma. Puberty was defined as the $1^{\text {st }}$ day that progesterone determined in blood samples collected at weekly intervals exceeded $1 \mathrm{ng} / \mathrm{ml}$ (Jones et al., 1991 and Simpson et al. (1991). Buffalo heifers reached puberty with and weighed $340->350 \mathrm{~kg}$ were naturally mated. Age and live body weight at the first, second oestrus and at conception were recorded. Number of oestrus cases up to service time, length of ovarian or oestrous cycles were calculated.

\section{Progesterone assay:}

Direct radioimmunoassay technique (RIA) was performed for determination of plasma progesterone concentration using antibody-coated tubes kit (Diagnosis systems, laboratories Texas, USA) according to the 
produce outlined by the manufacture. According to the manufacture's information, the radioimmunoassay (RIA) of progesterone is a competition assay. Sample and standards are incubated with ${ }^{125}$ /-labeled progesterone, as tracer, in antibody-coated tubes. After incubation the content of tubes is aspirated and bound radioactivity is measured. A calibration curve is established and unknown values are determined by interpolation from the curve. The standard curve of progesterone ranged from 0 to 2.4 and 0 to 2.0 $\mathrm{ng} / \mathrm{ml}$. The intra-and inter assay coefficient of variation were 5.4 and $9.1 \%$, respectively.

\section{Statistical analysis:}

Data were statistically analyzed according to Snedecor and Cochran (1982). The significant differences among treatment groups were tested using Duncan's Multiple Range Test (Duncan, 1955).

\section{RESULTS AND DISCUSION}

\section{Number of ovarian cycles prior to puberty:}

Data in table (2) show that prior to puberty, no silent ovulations were detected (according to changes in Pg levels in blood plasma) in heifers of G1, but three heifers in this group showed the basal level of $\mathrm{Pg}$, while the others showed Pg spikes with average of $5.5-8 \mathrm{ng} / \mathrm{ml}$. On the other hand, two heifers in G2 showed two ovarian cycles ending with silent ovulation (one by each animal) versus 5 cycles in 5 heifers (one/animal) of G3.

These findings proved the early puberty in heifers of G2 (498.5 das) and G3 (454.7 d) as compared to G1 heifers (529.2 das), which suggest beneficial effect of feeding $Y C$ on stimulating the ovarian activity of buffalo heifers. The early expression of cyclicity by heifers in G2 and G3 was mainly associated with increasing nutritive values of diets due to YC supplementation (Table 1).

This was in agreement with the results of Moran et al. (1990), who found that the proportion of heifers showing oestrus before puberty was $20 \%$ ( $3 / 15$ animals). This trend is in accordance with the observations of Zedan (1995), who found that inadequate energy level in diet of lactating buffalo delayed the resumption of ovarian activity and impaired conception rate. It has been suggested that gonadotropin concentrations transiently increased prior to 22 wk of age in cow heifer (Schams et al. 1981 and Evans et al. 1992), but not all investigators have seen this early rise (Dodson et al., 1988). It has been suggested that an early increase in hypothalamic $\mathrm{GnRH}$ secretion is the main drive responsible for the early rise in gonadotropin release (Dyer, et al., 1990). Final maturation of gonadotropin secretion at puberty may be due to removal of some inhibitory influences at the hypothalamus or higher brain centers or the maturation of these areas (Dodson et al., 1988 and Schillo et al., 1992).

Hall et al. (1994) concluded that modest differences in energy intake influenced the timing of the pre-pubertal increase in pulsatile LH release. Hall et al. (1997) also found that growth promoters induce puberty by hastening the normal cascade of endocrine and ovarian events associated with 
spontaneous puberty. Furthermore, age seemed to be the critical factor influencing the efficacy of growth promoters to induce puberty in heifers.

Table (2): Number of ovarian cycles exhibited by heifers in different experimental periods in response to yeast culture supplementation.

\begin{tabular}{|c|c|c|c|c|c|c|c|c|c|}
\hline \multirow{3}{*}{ Experimental period } & \multicolumn{9}{|c|}{ Experimental group } \\
\hline & \multicolumn{3}{|c|}{ G1(Control) } & \multicolumn{3}{|c|}{ G2 (20 g YC) } & \multicolumn{3}{|c|}{ G3 (30 g YC) } \\
\hline & $\mathbf{N}$ & $\mathbf{n}$ & $\begin{array}{l}\text { Cycles/ } \\
\text { animal }^{*}\end{array}$ & $\mathbf{N}$ & $\mathbf{n}$ & $\begin{array}{l}\text { Cycles/ } \\
\text { animal }\end{array}$ & $\mathbf{N}$ & $\mathbf{n}$ & $\begin{array}{l}\text { Cycles/ } \\
\text { animal }\end{array}$ \\
\hline Prior to puberty & - & - & - & 2 & 2 & & 5 & 5 & \\
\hline Puberty to $1^{\text {st }}$ service & 4 & 6 & 1 & 4 & 5 & 0.83 & 4 & 4 & 0.67 \\
\hline $1^{\text {st }}$ service to conception & 2 & 3 & 0.5 & 1 & 1 & 0.17 & 3 & 3 & 0.5 \\
\hline Overall mean & 5 & 9 & 0.5 & 4 & 8 & 0.44 & 6 & 12 & 0.66 \\
\hline
\end{tabular}

Number of ovarian cycles from puberty to $1^{\text {st }}$ service:

Four animals in each group showed ovarian cycles, being the highest in G1 (6 cycles, averaging one/animal), moderate in G2 (5 cycles, averaging 0.83 /animal) and the lowest in G3 (4 cycles, averaging 0.67/animal). From these cycles one ended with silent ovulation in each of $\mathrm{G} 2$ and $\mathrm{G} 1$, however, heifers in G3 did not exhibit cycles with silent ovulation (Table 2).

The pronounced increase in number of ovarian cycles in the control group resulted from incidence of puberty in 5 animals before reaching the appropriate weights for mating and/or incidence of one cycle ending with silent ovulation. The tendency of higher number of ovarian cycles in $\mathrm{G} 1$ (one cycle/heifer) than that in G2 and G3 ( 0.83 and 0.67 cycles/heifer) may be associated with net energy level in these groups, being the highest in G3, followed by G2, and the lowest in the control group. This come in line with results reported on Egyptian buffalo heifers by Shahin (2004), who found that number of oestrous cycles from puberty to $1^{\text {st }}$ service was significantly affected $(P>0.05)$ by dietary energy level, being higher ( 4.5 cycles/animal) in buffalo heifers fed $80 \%$ TDN diet than those fed 100\% TDN diet $(2.3$ cycles/animal), but increasing level of dietary TDN to $120 \%$ did not differ significantly these numbers from those in 80 and $100 \%$, being 3.2 cycles/animal).

\section{Number of ovarian cycles from $1^{\text {st }}$ service to conception:}

Two animals in G1 showed 3 ovarian cycles with an average of 0.50 /animal versus one animal in G2 showed one cycle averaging 0.17 /animal, and 3 animals in G3 showed 3 cycles averaging 0.50/animal (Table 2).

Decreasing average number of ovarian cycles in G2 (0.17/animal) than those in $\mathrm{G} 3$ and $\mathrm{G} 1$ (0.5/animal) during the interval from $1^{\text {st }}$ service to conception was mainly related to that 2 animal in $\mathrm{G} 1$, one of them showed one cycle with silent ovulation and 3 in G3 returned to oestrus after the $1^{\text {st }}$ service versus one animal in G2.

In contrast to the present results, Shahin (2004) found that number of oestrous cycles from $1^{\text {st }}$ service to conception in Egyptian buffalo heifers was 
affected significantly $(P>0.05)$ by dietary energy level, being higher (6.5 cycles/animal) in heifers fed $80 \%$ TDN diet than those fed $100 \%$ TDN diet (4.8 cycles/animal), but did not significantly differ from those in 80 and $100 \%$ by increasing level of dietary TDN to $120 \%$, being 5.1 cycles/animal). These findings indicated no incidence of ovarian cycles with silent ovulation in heifers fed $Y C$ in G2 and G3 after the $1^{\text {st }}$ service, which could be attributed to dietary protein rather than energy level.

The differences in average number of the ovarian cycles prior to puberty and from puberty to $1^{\text {st }}$ service reflected highest overall number of ovarian cycles up to conception in G3 (0.66/animal), followed by $\mathrm{G} 1$ (0.5/animal). While heifers in G2 showed the lowest values (0.44/animal) (Table 2). This was in accordance with average number of service/conception and service period length in each group.

Inadequate nutrition adversely affected the pituitary function through the pattern of releasing and/or producing the pituitary gonadotrphins (Lamminy, 1969). The nutrition state of the animal is unlikely influenced the incidence of the behavioral oestrous and therefore it would be a limiting factor of reproductive performance (Speedy, 1995).

Ovarian cycle length:

Prior to puberty incidence, the ovarian cycles detected in G2 were shorter than those in G3 (12.5 vs. 30.0 days). The ovarian cycles were characterized as short in G2 and long in G3 (Table 3). This may indicate that most pre-puberty oestrous cycles are abnormal and ending with silent ovulation (Table 3).

From puberty to $1^{\text {st }}$ service and from $1^{\text {st }}$ service to conception, the detected ovarian cycles were almost longer in heifers of G3 (23.7 and 23.0 days) than in G2 (18.4 and 21.0 days) and G1 (19.3 and 22.3 days), respectively). However, oestrous cycle length was longer from $1^{\text {st }}$ service to conception than from puberty to $1^{\text {st }}$ service in $\mathrm{G} 2$ and $\mathrm{G} 1$ only (Table 3). These cycles may be characterized as normal cycles (Between 17-23 days) as reported by El-Moghazy (2003), which may indicate normal oestrous cycles post puberty than pre-puberty.

Table (3): Ovarian cycle length of buffalo heifers as affected by yeast culture supplementation.

\begin{tabular}{|c|c|c|c|c|c|c|}
\hline \multirow{3}{*}{ Experimental interval } & \multicolumn{6}{|c|}{ Ovarian cycle length } \\
\hline & \multicolumn{2}{|r|}{ G1 } & \multicolumn{2}{|r|}{ G2 } & \multicolumn{2}{|r|}{ G3 } \\
\hline & $\mathbf{N}$ & Length (d) & $\mathbf{N}$ & Length (d) & $\mathbf{N}$ & Length (d) \\
\hline Prior to puberty & - & - & 2 & $12.5 \pm 1.5$ & 5 & $30.0 \pm 3.1$ \\
\hline Puberty to $1^{\text {st }}$ service & 6 & $19.3 \pm 2.4$ & 5 & $18.4 \pm 1.2$ & 4 & $23.7 \pm 0.95$ \\
\hline $1^{\text {st }}$ service to conception & 3 & $22.3 \pm 8.4$ & 1 & $21.0 \pm 0.0$ & 3 & $23.0 \pm 2.0$ \\
\hline Overall mean & 9 & $20.3 \pm 2.9$ & 8 & $17.3 \pm 1.4$ & 12 & $26.1 \pm 1.6$ \\
\hline
\end{tabular}

$\mathrm{N}=$ Number of cycles

Overall length of oestrous cycles from pre-puberty up to conception was the highest in heifers of G3 (26.1 days), moderate in G1 (20.3 days) and the lowest in G2 (17.3 days). This effect on buffalo heifers contrasted those reported on postpartum buffalo cows reported by Ibrahim (2004). 


\section{Ovulatory activity:}

Prior to puberty, all detected ovulations in heifers of G2 and G3 were silent, being greater 0.33 /animal in G2 than G3 (0.83/animal). However, no detected ovulations in G1 (Table 4). These findings indicated higher ovulatory activity in heifers fed diets supplemented with 20 and $30 \mathrm{~g}$ YC than those fed D1 (G1), being the highest in those fed 30 than $20 \mathrm{~g} \mathrm{YC}$.

From puberty to $1^{\text {st }}$ service, average number of all detected ovulations was the greatest in $\mathrm{G} 1$ (2.0/animal), followed by G2 (1.83/animal), and the least in G3. Of all ovulations, G1 showed greater number of oestrous ovulations (1.83/animal) than those in G2 and G3 (1.67/animal in each).

Interestingly to note that no silent ovulations were found in $G 3$, however, one heifer in each of G1 and G2 showed one silent ovulation, averaging 0.17/animal, and representing 8 and $9 \%$ of all ovulation, respectively (Table 4$)$.

Table (4): Means and standard errors of number of ovulations from puberty to $1^{\text {st }}$ service and to conception of buffalo heifers in different experimental groups.

\begin{tabular}{|c|c|c|c|c|c|c|c|c|c|c|c|c|}
\hline \multirow{3}{*}{$\begin{array}{l}\text { Number of } \\
\text { Ovulations }\end{array}$} & \multicolumn{12}{|c|}{ Experimental group } \\
\hline & \multicolumn{4}{|c|}{ G1 } & \multicolumn{4}{|c|}{ G 2} & \multicolumn{4}{|c|}{ G3 } \\
\hline & $\mathbf{n}$ & $\mathbf{M}$ & $\%$ & $\%^{*}$ & n 1 & & $\%$ & $\%^{*}$ & $\mathbf{n}$ & $\mathbf{M}$ & $\%$ & $\%^{*}$ \\
\hline \multicolumn{13}{|c|}{ Through pre-pubertal period: } \\
\hline S.O./cow & - & - & - & - & 2 & 0.33 & \multicolumn{2}{|c|}{\begin{tabular}{l|l|l|l|}
100 & 3.3
\end{tabular}} & 5 & 0.83 & 100 & 83 \\
\hline \multicolumn{13}{|c|}{ From puberty to $1^{\text {st }}$ service: } \\
\hline O.O. & 11 & 1.83 & 92 & 100 & 10 & 1.67 & 91 & 100 & 10 & 1.67 & 100 & 100 \\
\hline S.O. & 1 & 0.17 & 8 & 16.7 & 1 & 0.17 & 9 & 16.7 & 0 & 0 & 0 & 0 \\
\hline T.O./cow & 12 & 2.00 & 100 & - & 11 & 1.83 & 100 & - & 10 & 1.67 & 100 & - \\
\hline \multicolumn{13}{|c|}{ From $1^{\text {st }}$ service to conception: } \\
\hline 0.0 & 2 & 0.33 & 67 & 33.3 & 1 & 0.17 & 100 & 16.7 & 3 & 0.50 & 100 & 50 \\
\hline S.O & 1 & 0.17 & 33 & 16.7 & 0 & 0 & 0 & 0 & 0 & 0 & 0 & 0 \\
\hline T.O./cow & 3 & 0.50 & 100 & - & 1 & 0.17 & 100 & - & 3 & 0.50 & 100 & - \\
\hline \multicolumn{13}{|c|}{ From pre-pubertal to conception: } \\
\hline O.O. & 13 & 2.17 & 87 & 100 & 11 & 1.83 & 79 & 100 & 13 & 2.17 & 72 & 100 \\
\hline S.O. & 2 & 0.33 & 13 & 33.3 & 3 & 0.50 & 21 & 33.3 & 5 & 0.83 & 28 & 83 \\
\hline T.O. /cow & 15 & 2.50 & 100 & - & 14 & 2.33 & 100 & - & 18 & $3 \pm 0.3$ & 100 & - \\
\hline
\end{tabular}

$\%^{*}$ : Percentage of buffalo cows showing ovulation \%: As a percentage of total ovulations S.O.: Silent ovulations O.O.: Oestrous ovulations T.O.: Total ovulations $\mathbf{N}$ :Number of cases $\mathbf{M}$ :Mean

The pronounced reduction in average number of total ovulations in heifers of G3 was attributed to incidence of lesser oestrous ovulations and no incidence of silent ovulations as compared to $\mathrm{G} 2$ and $\mathrm{G} 1$, respectively.

From $1^{\text {st }}$ service to conception, average number of all detected ovulations was greater in $\mathrm{G} 1$ and $\mathrm{G} 3$ (0.5/animal) than in $\mathrm{G} 2$ (0.17/animal). One case of silent ovulation occurred in $\mathrm{G1}$, averaging 0.17 /animal and representing $33 \%$ of all ovulations. While in heifers of G2 and G3, no incidence of silent ovulations was recorded. This resulted in reducing average number of ovulations in heifers of G2 (Table 4).

The pronounced increase in average number of ovulations in heifers of $\mathrm{G} 3$ and $\mathrm{G} 1$ as compared to $\mathrm{G} 2$ was associated with higher conception rate in G2 versus 3 and 4 animals in G3 and G1, respectively (Table 4). 
Abdel-Khalek, E.A. et al.

Overall number of all ovulations (Table 4) during the period from prepuberty up to conception was greater in G3 (3.0/animal) than in G1 and G2 (2.5 and 2.33/animal, respectively). Number of silent ovulations was the greatest in G3 (0.83/animal), followed G2 (0.50/animal), and the least in G1 (0.33/animal).

The higher percentage of silent ovulations in G2 (21\%) and G3 (28\%) than $\mathrm{G} 1(13 \%)$ was due to higher incidence of silent ovulations in G2 and G3 (2 and 5 ovulations, respectively during the pre-puberty period (Table 3 ).

The effect of $Y C$ on decreasing number of ovulations from puberty to conception in heifers of G3 was nearly similar to that observed by Ibrahim (2004) on postpartum buffaloes. Increasing post-weaning weight gain of light weight heifers from 0.07 to $1.17 \mathrm{~kg} / \mathrm{d}$ increased both reproductive performance (Buskirk et al., 1995).

\section{Progesterone profile:}

Data in table (5) revealed that the highest $\mathrm{Pg}$ concentration was detected in G3 $(1.971 \mathrm{ng} / \mathrm{ml})$, followed by that in $\mathrm{G} 1(1.403 \mathrm{ng} / \mathrm{ml})$ and the lowest values were observed in G2 $(0.957 \mathrm{ng} / \mathrm{ml})$. It is worthy noting that, peak of $\mathrm{Pg}$ concentration in the experimental groups was associated with average concentration of $\mathrm{Pg}$, but the differences were significant $(P<0.05)$, being higher by about $65 \%$ in G3 and lower in G2 by about $48 \%$ than G1. Age at Pg peak tended to be insignificantly earlier in G2 and G3 (491.5 and 472.1 days, respectively) compared with G1 (519.6 days), but was earlier in G3 than G2.

Based on these results, it could be seen that buffalo heifers in G3 showed higher ovarian activity than that in G2 and G1, indicating the efficiency of feeding buffalo heifers on diets supplemented with $30 \mathrm{~g} \mathrm{YC}$ to reach early puberty.

From puberty to $1^{\text {st }}$ conception, only interval to $\mathrm{Pg}$ peak within the ovarian cycles was significantly $(P<0.05)$ affected by the dietary treatment. However, average $\mathrm{Pg}$ concentration and $\mathrm{Pg}$ peak did not significantly differ among the experimental groups. Average and $\mathrm{Pg}$ peak and interval to peak showed the highest values in G3, moderate in G1 and the lowest in G2. It is was observed also that average concentration of $\mathrm{Pg}$ was almost associated with values of $\mathrm{Pg}$ peak and the interval to peak, being the highest in $\mathrm{G} 3$, followed by G1 and the lowest in G2 (Table 5), which was associated with ovarian cycle length (Table 5 ).

It is worthy noting that the youngest age of buffalo heifers in G3 at Pg peak was associated with the earliest age at puberty, $1^{\text {st }}$ service and conception. The opposite was found in G1, however, heifers in G2 showed moderate ages. These findings may explain the effect of the high level of YC $(30 \mathrm{~g} / \mathrm{h} / \mathrm{d})$ on increasing $\mathrm{Pg}$ concentration and the low level $(20 \mathrm{~g} / \mathrm{h} / \mathrm{d})$ on decreasing Pg concentration during post-puberty ovarian cycles.

On the basis of these findings, it was observed that heifers fed the high level of $Y C$ (G3) showed long ovarian cycles as a result of increasing interval to Pg peak and increasing average concentration of $\mathrm{Pg}$. The opposite was observed with the low level of $Y C$ in G2. 
During ovarian cycle at conception, only interval to $\mathrm{Pg}$ peak within the ovarian cycles was affected significantly $(P<0.05)$ by the dietary treatment.

During early pregnancy, only interval to $\mathrm{Pg}$ peak within the ovarian cycles was significantly affected $(P>0.05)$ by the dietary treatment. While, maximum $\mathrm{Pg}$ concentration during the first two weeks of pregnancy was insignificantly the highest in G3, moderate in G1 and lowest in G2 (Table 5).

These results indicated that $\mathrm{Pg}$ concentration was almost the highest in G3 during pre-puberty, ovarian cycles and ovarian cycle at conception and pregnancy indicating higher effect of the high level of $\mathrm{YC}$ on $\mathrm{Pg}$ concentration.

Table (5): Means and standard errors of progesterone concentration during pre-pubertal age, ovarian cycles from puberty to conception, ovarian cycle ending with conception, and pregnancy for buffalo heifers in different groups.

\begin{tabular}{|c|c|c|c|}
\hline \multirow{2}{*}{ Item } & \multicolumn{3}{|c|}{ Experimental group } \\
\hline & G 1 & G 2 & G3 \\
\hline \multicolumn{4}{|c|}{ Pg concentration $(\mathrm{ng} / \mathrm{ml})$ prior to puberty: } \\
\hline Average & $1.403 \pm 0.73$ & $0.957 \pm 0.27$ & $1.971 \pm 0.48$ \\
\hline Pg peak & $3.798 \pm 1.57^{\mathrm{ab}}$ & $1.987 \pm 0.94^{\mathrm{b}}$ & $6.267 \pm 1.42^{\mathrm{a}}$ \\
\hline Age at Pg peak (day) & $519.66 \pm 17.43$ & $491.50 \pm 25.3$ & $472.17 \pm 15.68$ \\
\hline \multicolumn{4}{|c|}{ Pg concentration (ng/ml) during ovarian cycle from puberty to conception: } \\
\hline Average & $2.21 \pm 0.66$ & $1.56 \pm 0.60$ & $3.88 \pm 1.03$ \\
\hline Pg peak & $4.90 \pm 1.42$ & $3.79 \pm 1.36$ & $7.25 \pm 0.87$ \\
\hline Interval to Pg peak (day) & $13.13 \pm 2.9^{\mathrm{ab}}$ & $9.63 \pm 1.72^{\mathrm{a}}$ & $16.69 \pm 1.82^{\mathrm{b}}$ \\
\hline \multicolumn{4}{|c|}{ Pg concentration $(\mathrm{ng} / \mathrm{ml})$ during ovarian cycle ending with conception: } \\
\hline Average & $2.36 \pm 0.78$ & $1.41 \pm 0.52$ & $3.27 \pm 0.55$ \\
\hline Pg peak & $5.46 \pm 1.84$ & $3.81 \pm 1.38$ & $7.38 \pm 1.27$ \\
\hline Interval to Pg peak (day) & $11.83 \pm 3.36$ & $9.33 \pm 1.8$ & $13.83 \pm 2.02$ \\
\hline \multicolumn{4}{|c|}{ Pg concentration during pregnancy: } \\
\hline Maximum Pg (ng/ml) & $6.63 \pm 1.48$ & $3.88 \pm 0.62$ & $7.51 \pm 1.91$ \\
\hline
\end{tabular}

a and b: Group means denoted within the same row with different superscripts are significantly different.

The effect of $Y C$ at a high level may be explained by increasing the dietary energy level. Lammoglia et al. (2000) found that high-energy diet affected progesterone $(\mathrm{P}<0.05)$ concentration. Simpson et al. (1991) proposed that somatotropin and insulin like growth factor-1 (IGF-I) are important metabolic mediators involved in the initiation of puberty in heifers.

Conception rate:

Data in table (6) reveal that number of services per conception and service period lower in G2and higher in G3 than G1. This was attributed to that more heifers in $\mathrm{G} 3(83.3 \%)$ conceived from the $1^{\text {st }}$ service versus $66.7 \%$ in $\mathrm{G} 1$ and $50 \%$ in $\mathrm{G} 3$. However, few heifers (16.7\%) in G2 required two services/conception versus 33.3 and $50 \%$ in $\mathrm{G} 1$ and in G3.

In postpartum buffaloes fed $20 \mathrm{~g}$ Gustor nature as a $\mathrm{YC} / \mathrm{h} / \mathrm{d}$, Ibrahim (2004) found that all animal required one service to conceive. As affected by dietary energy level, Marston et al. (1995) found that pregnancy rates were significantly lower for heifers fed SBM-diet $(67 \%)$ than for low, high, and dry lot feeding heifers $(94,94$, and $86 \%$, respectively). 
However, Lammoglia et al. (2000) reported that high-energy diet did not affect number of Al services per conception and final pregnancy percentage. Also, Buskirk et al. (1995) found no significant differences in pregnancy rate or first-service calving rate between heifer groups fed high or low energy levels.

Table (6): Number of services/conception, service period and conception rate of buffalo heifers in different experimental groups.

\begin{tabular}{|c|c|c|c|}
\hline \multirow{2}{*}{ Item } & \multicolumn{3}{|c|}{ Experimental group } \\
\cline { 2 - 4 } & $\mathbf{G ~ 1}$ & $\mathbf{G ~ 2}$ & $\mathbf{G 3}$ \\
\hline Number of services/conception & $1.33 \pm 0.21$ & $1.17 \pm 0.17$ & $1.50 \pm 0.22$ \\
\hline Service period (day) & $10.8 \pm 8.3$ & $3.8 \pm 0.00$ & $14.7 \pm 6.83$ \\
\hline Conception rate (\%) & 66.7 & 83.3 & 50 \\
\hline $1^{\text {st }}$ & 33.3 & 16.7 & 50 \\
\hline $2^{\text {nd }}$ & 100 & 100 & 100 \\
\hline Total
\end{tabular}

\section{REFERENCES}

Aboul-Ela, M.B. (1980). A study of the vaginal electrical resistance in cattle as related to hormone changes and its application in the detection of oestrus. Ph. D. Thesis, University of Aberdeen, UK.

Aboul-Ela, M.B.; El-Keraby, F.E. and Khattab, R.M. (1985). Effect of GnRH treatment on post-partum resumption of oestrus and ovulation in buffaloes. Buffalo J., 1: 61-69.

Aboul-Ela, M.B.; Khattab, R.M.; El-Keraby, F.E.; Shafie, M.M. and Bedier, L.H. (1987). Patterns of ovarian and oestrus activity and induction of cyclic activity during the post-partum periods in Egyptian buffaloes. Proceeding of the $3^{\text {rd }}$ research co-ordination meeting on optimizing grazing animal productivity in the Mediterranean and North African Regions with the Aid of Nuclear Techniques. Rabat, Morocco, March 23-27, pp. 236-254.

Arora, R.C. and Pandy, R.S. (1982). Current research statues of buffalo reproductive endocrinology. World Review Anim-predi, 18 (2): 15-23.

Barkawi, A.H. (1993). Post-partum reproductive pattern of suckling and nonsukling Egyptian buffaloes. Egyptian J. Anim. Prod. 30:129-142.

Barkawi, A.H.; Shafie, M.M.; Mekawy, Y. and Aboul-Ela, M.B. (1986). The use of serum and milk progesterone concentration to monitor postpartum ovarian activity in Egyptian buffaloes. Buffalo. J. 2: 125-134.

Beg, M.A. and Totey, S.M. (1999). The oestrus cycle, oestrus behaviour and the endocrinology of the oestrus cycle in buffalo (Bubalus bubalis). Anim. Breed. Abst., 67: 329-337.

Buskirk, D.D.; Faulkner, D.B. and Ireland, F.A. (1995). Increased postweaning gain of beef heifers enhances fertility and milk production. $\mathrm{J}$. Anim. Sci., 73: 937-946. 
Day, M.L.; Imakawa, K.; Wolf, P.L.; Kittok, R.J. and Kinder, J.E. (1987). Endocrine mechanisms of puberty in heifers: role of hypothalamopituitary estradiol receptors in the negative feedback of estradiol on luteinizing hormone secretion. Biol Reported; 37:1054-1065.

Dodson, S.E.; McLeod, B.J.; Haresign, W.; Peters, A.R. and Lamming, G.E. (1988). Endocrine changes from birth to puberty in the heifer. J. Reproduction and Fertility, 82:527-538.

Duncan, D.B. (1955). Multiple Range and Multiple F. test. Biometrics, 11:10.

Dyer, R.M.; Bishop, M.D.; Day, M.L. (1990). Exogenous estradiol reduces inhibition of luteinizing hormone by estradiol in prepubertal heifers. Biol Reprod; 42:755-761.

El-Moghazy, M.M.M. (2003).Physiological studies on the post partum in buffalos. Ph.D. Thesis, Fac. Agric., Mansoura Univ., Egypt.

El-Wardani, M.A.; Enaam, M. Mokhless and Barkawi, A.H. (1998). Effect of bull exposure system on post-partum reproductive performance of hot season buffalo calvers. Egypt. J. Anim. Prod. 35: 533-541.

Evans, A.C.O.; Adams, G.P.; Rawlings, N.C. (1994). Follicular and hormonal development in prepubertal heifers from 2 to 36 weeks of age. J. Reprod. Fertil.; 102:463-470.

Evans, A.C.O.; Currie, W.D. and Rawlings, N.C. (1992). Effects of naloxone on circulating gonadotrophin concentrations in prepubertal heifers. $J$ Reprod Fertil; 96:847-855.

Hafez E.S.E. (1987). Reproductive in farm animals. $5^{\text {th }}$ Ed. Lea and Febiger, 600 Washington Square, Philadelphia, PA 19106-4198 USA, 315-325.

Hall, J.B.; Staigmiller, R.B. Short, R.E. Bellows, R.A. MacNeil, M.D. and Bellows, S.E. (1997). Effect of age and pattern of gain on induction of puberty with a progestin in beef heifers. J. Anim. Sci., 75: 1606-1611.

Hall, J.B.; K.K. Schillo, B.P. Fitzgerald and N.W. Bradley (1994). Effects of recombinant bovine somatotropin and dietary energy intake on growth, secretion of luteinizing hormone, follicular development, and onset of puberty in beef heifers. J. Anim. Sci., 72: 709-718.

Ibrahim, S.E.A. (2004). Physio-Nutritional studies on Egyptian buffaloes. Ph.D. Thesis, Mansoura University, Egypt.

Ireland, J.J.; Curato, A.D. and Wilson, J. (1983). Effect of charcoal-treated bovine follicular fluid on secretion of $\mathrm{LH}$ and $\mathrm{FSH}$ in ovariectomized heifers. J Anim Sci; 57:1512-1516.

Jones, E.J.; J.D. Armstrong and R.W. Harvey (1991). Changes in metabolites, metabolic hormones, and luteinizing hormone before puberty in Angus, Braford, Charolais, and Simmental heifers. J. Anim. Sci., 69: 1607-1615.

Kamonpatana, M.; Virajul, P. Kunawongkrit, C.L.A.; Ngramsuriyaroj, C. and Mathais, E.I. (1981). Plasma progesterone, oestrus sulphate and LH levels during pregnancy, parturition and post-partum in the Swamp buffaloes. Proceedings of second coordination meeting or regional cooperative agreement on the use of nuclear techniques to imptrove domestic buffalo production in Asia, Bangkok, Thailand, pp. 124-136. 
Lamminy, E.E. (1969). Nutrition and Reproductive in: The Science of Nutrition of Livestock. Edited by D. Cuthbertson Pergman, Press, London.

Lammoglia, M.A.; Bellows, R.A.; Grings, E.E.; Bergman, J.W.; Bellows, S.E.; Short, R.E.; Hallford, D.M. and Randel, R.D. (2000). Effects of dietary fat and sire breed on puberty, weight, and reproductive traits of $\mathrm{F} 1$ beef heifers. J. Anim. Sci., 78: 2244-2252.

McLeod, B.J.; Peters, A.R.; Haresign, W. and Lamming, G.E. (1985). Plasma $\mathrm{LH}$ and $\mathrm{FSH}$ responses and ovarian activity in prepubertal heifers treated with repeated injections of low doses of $\mathrm{GnRH}$ for $72 \mathrm{~h}$. J Reprod Fertil; 74:589-596.

Marston, T.T.; Lusby, K.S. and Wettemann, R.P. (1995). Effects of postweaning diet on age and weight at puberty and mild production of heifers. J. Anim. Sci., 73: 63-68.

Mejia, M.; Gonzalez-Iglesias, A. Diaz-Torga, G. S. Villafane, P. Formia, N. Libertun, C. Becu-Villalobos, D. and Lacau-Mengido, I. M. (1999). Effects of continuous ivermectin treatment from birth to puberty on growth and reproduction in dairy heifers. J. Anim. Sci., 77: 1329-1334.

Moran, C.; Prendiville, D.J. Quirke, J.F. and Roche, J.F. (1990). Effects of oestradiol, zeranol or trenbolone acetate implants on puberty, reproduction and fertility in heifers. J. Reproduction and Fertility, 89:527-536.

Perera, B.M.A.O. (1981). The use of hormone measurement for studying reproductive patterns of buffaloes in Sir Lanka. The $2^{\text {nd }}$ Coordination Meeting of the Regional Cooperative Agreement on the Use of Nuclear Techniques to Improve Domestic Buffalo Production in Asia, Bangkok, Thailand, March 2-6 Part I, pp. 149-158.

Schams, D.; Schallenberger, E.; Gome, S. and Karg, H. (1981). Endogenous patterns associated with puberty in male and female cattle. J Reprod Fertil Suppl; 30:103-110.

Schillo, K.K.; J.B. Hall and S.M. Hileman (1992). Effects of nutrition and season on the onset of puberty in the beef heifer. J. Anim. Sci., 70: 3994-4005.

Shahin, G.F. (2004). Effect of dietary energy level on: 2- Nutrient utilization, productive and reproductive performances of growing buffalo heifers. Egypt. J. Nutr. And Feeds, 7-(2): 143-154.

Simpson, R.B.; Armstrong, J.D.; Harvey, R.W.; Miller, D.C.; Heimer, E.P. and Campbell, R.M. (1991). Effect of active immunization against growth hormone-releasing factor on growth and onset of puberty in beef heifers. J. Anim. Sci., 69:4914-4924.

Snedecor, G.W. and Cochran, W.G. (1982). Statistical Methods. $7^{\text {th }}$ Ed. lowa Univ. Press, Ames. lowa, USA.

Speedy, A.W. (1995). Progress in sheep and goat Researches. Department of plant Science, Univ of Oxford U.K.

Zedan, K.I. (1995). Effect of dietary energy on the performance of milking buffaloes. M. Sc. Thesis, Faculty of Agiculture, Shebin El-Kom, Menoufiya University. 


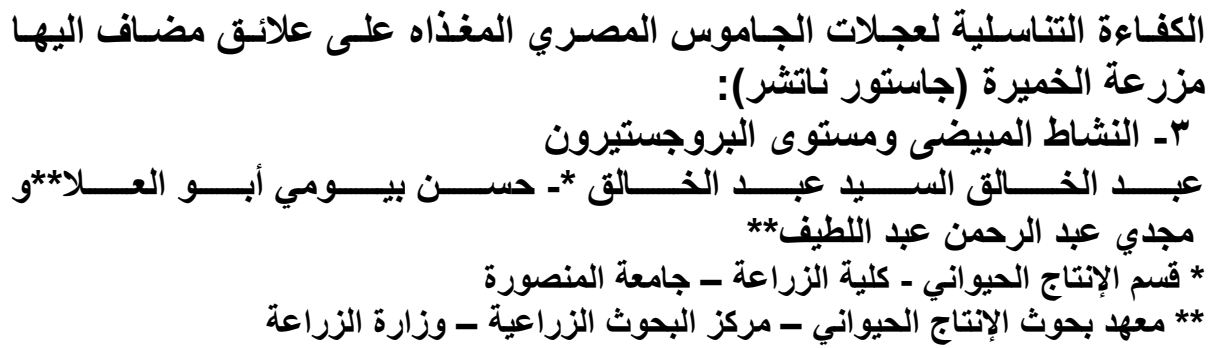

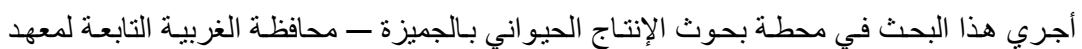

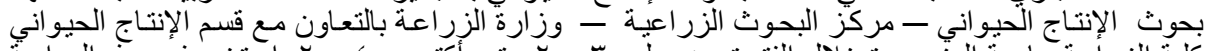

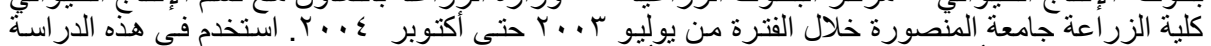

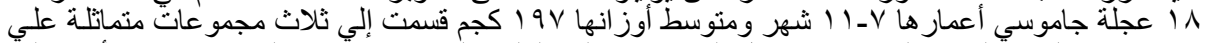

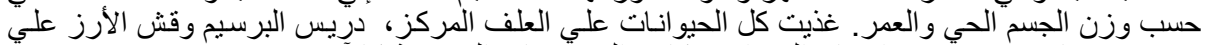

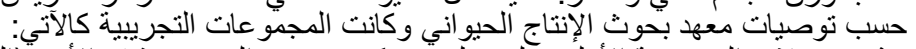

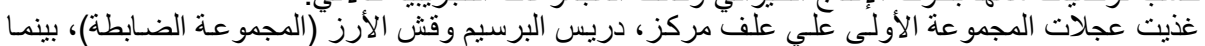

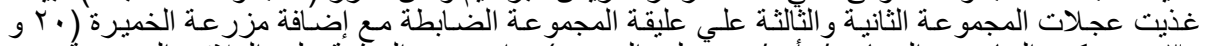

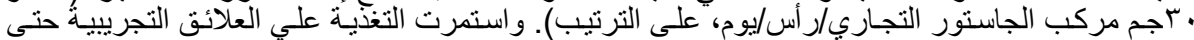

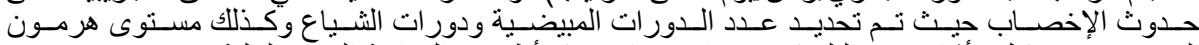

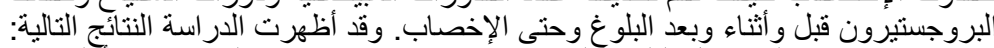

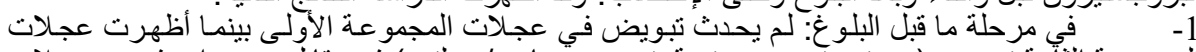

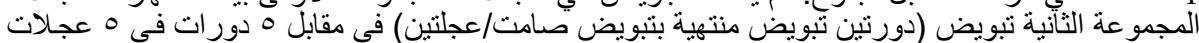

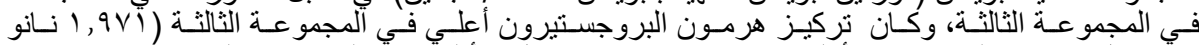

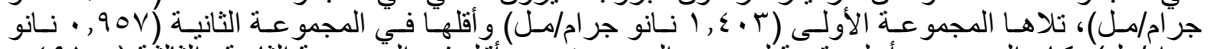

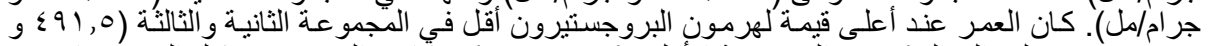

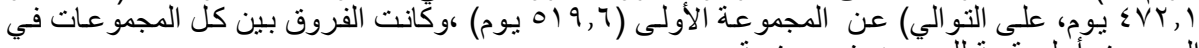

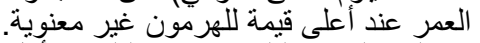

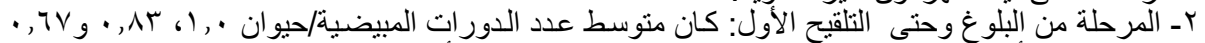

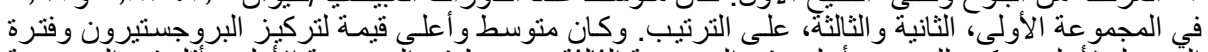

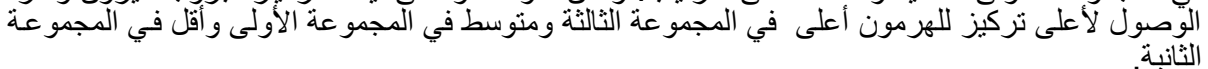

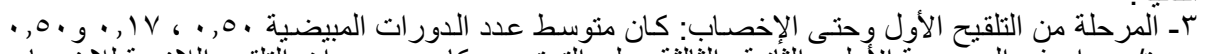

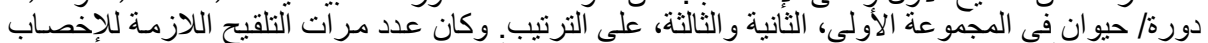

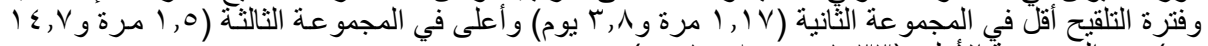

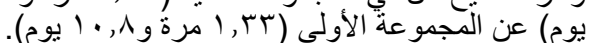

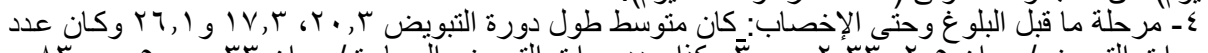

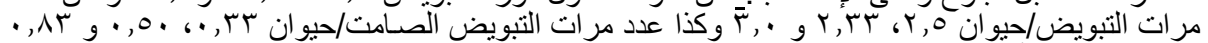

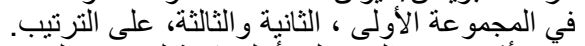

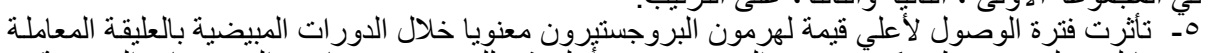

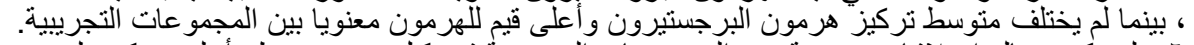

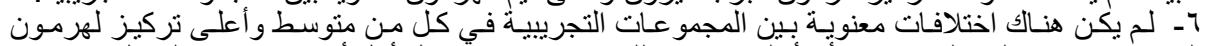

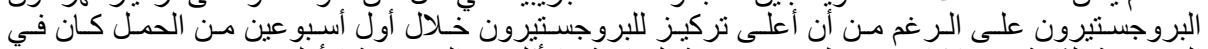

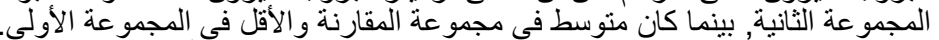

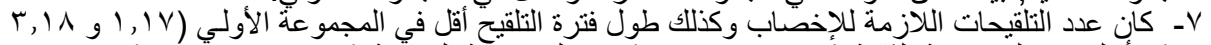

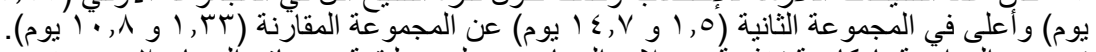

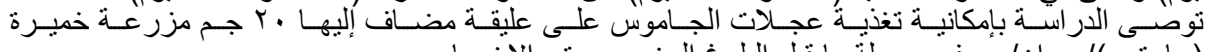

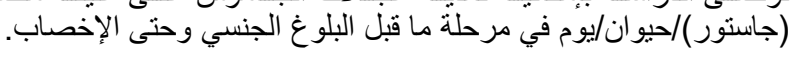

